\title{
Editorial
}

\section{Progress in Water Footprint Assessment: Towards Collective Action in Water Governance}

\author{
Arjen Y. Hoekstra ${ }^{1,2, * \mathbb{D}}$, Ashok K. Chapagain ${ }^{3}$ and Pieter R. van Oel ${ }^{4} \mathbb{D}$ \\ 1 Twente Water Centre, University of Twente, 7500AE Enschede, The Netherlands \\ 2 Institute of Water Policy, Lee Kuan Yew School of Public Policy, National University of Singapore, \\ Singapore 259770, Singapore \\ 3 Agricultural Economics, University of the Free State, Bloemfontein 9301, South Africa; \\ chapagainak@ufs.ac.za \\ 4 Water Resources Management Group, Wageningen University, P.O. Box 47, 6700AA Wageningen, \\ The Netherlands; pieter.vanoel@wur.nl \\ * Correspondence: a.y.hoekstra@utwente.nl
}

Received: 9 April 2019; Accepted: 21 May 2019; Published: 23 May 2019

check for updates

\begin{abstract}
We introduce ten studies in the field of water footprint assessment (WFA) that are representative of the type of papers currently being published in this broad interdisciplinary field. WFA is the study of freshwater use, scarcity, and pollution in relation to consumption, production, and trade patterns. The reliable availability of sufficient and clean water is critical in sustaining the supply of food, energy, and various manufactured goods. Collective and coordinated action at different levels and along all stages of commodity supply chains is necessary to bring about more sustainable, efficient, and equitable water use. In order to position the papers of this volume, we introduce a spectrum for collective action that can give insight in the various ways different actors can contribute to the reduction of the water footprint of human activities. The papers cover different niches in this large spectrum, focusing on different scales of governance and different stages in the supply chain of products. As for future research, we conclude that more research is needed on how actions at different spatial levels and how the different players along supply chains can create the best synergies to make the water footprint of our production and consumption patterns more sustainable.
\end{abstract}

Keywords: water footprint assessment; multi-level governance; value chain; consumption; international trade; river basin management; sustainability; water accounting; water productivity; water footprint benchmarks

\section{Introduction}

We present here the fifth special collection of papers in the field of water footprint assessment (WFA). The first collection was a special issue published in Water over the years 2010-2011 [1]. A second volume followed in the journal Water Resources and Industry in 2013 [2], a third volume in Sustainability in 2015 [3], and a fourth volume in Water in the years 2016-2017 [4]. Each of the volumes contains a snapshot of what was being researched in the field at the time of publication. This is also true for the current collection of papers. The red line over the years is the interdisciplinarity of the studies and diversity of the subjects researched. The progress lies in the gradual shift in focus from accounting to what we can learn from the accounts for better water governance at different levels and better supply chain management, as illustrated by this latest collection of papers. Water footprint assessment (WFA) is the study of freshwater use, scarcity, and pollution in relation to consumption, production, and trade [5]. By nature, the field is integrative, bringing together different disciplines and perspectives, for instance, natural sciences, policy studies, and geographical and supply-chain 
perspectives. It links water issues to food, energy, and climate and addresses issues of sustainability, efficiency, and equitability of resource use. All these themes come back in the various papers in the current volume. What makes this new field of research so exciting is that it opens up ways to analyze linkages between previously disconnected fields of study and that it offers a much broader perspective on how we can approach the solution of the water scarcity and pollution problems that people are facing in so many places today, in either direct or indirect ways.

Historically, interventions in response to water shortages have mostly aimed at increasing either water supply or water-use efficiency, interpreting efficiency narrowly as the ratio of output to input [6]. Unfortunately, the scope for finding sustainable, equitable, and resilient solutions through these types of interventions is limited. Moreover, because of the complexities and feedbacks in human-environmental interactions, it is less than straightforward to understand the redistributive effects of building reservoirs [7] and promoting micro-irrigation technologies [8]. Water demand is projected to grow because of continued population and economic growth while water availability in critical periods is expected to decrease in many places because of climate change [9] so that the need to act and mitigate water scarcity only becomes more pressing. Apart from actors in water resource management (e.g., irrigation boards, water boards, river basin committees, water ministries) and agricultural water management (e.g., farmers, farmer associations, agricultural ministries), there are multiple others that have an effect on the way we mobilize the world's water resources for producing the goods and services we wish to consume. Patterns of water use, scarcity, and pollution are intricately related to the way we have organized our economies. As a result, wise water governance inevitably means that we have to look beyond managing water resources use itself. We need to consider also indirect drivers of water problems, like incentives to produce water-intensive products in water-scarce regions for export, governmental subsidy programs to shift from fossil fuels to biofuels, and lack of mechanisms to reduce wastage of food along all stages of the supply chain. Next, we need to look at ways in which actors outside the water field can contribute to the indirect solution of the water problems. Figure 1 shows the spectrum of collective action that we need to consider to understand how we can effectively reduce water footprints of human activities to sustainable levels, by interventions through different actors along supply chains and at different scale levels. We can distinguish different types of interventions:

(1) Interventions at different scale levels: from the field or production-line level to the farm or factory level, the river basin level, the country level, and the international level.

(2) Interventions in different stages of the supply chain: from production, trade, processing, international markets and auctions to distribution, sale and household management;

Furthermore, we can distinguish between different types of actors:

(1) Actors at different governance levels: from the individual water user (e.g., farmer or factory manager) to irrigation and water boards, governmental policy makers, and international agreements;

(2) Actors in the different stages of the supply chain: from stockholders, investors, producers, processors, and traders to retailer and consumers.

The collection of papers that are presented here offers ten studies that form a reflection of the type of papers currently being published in the field of WFA. They illustrate the range of spatial intervention levels, each with different players, and show the relevance of considering different supply-chain stages, each of which can be identified with different actors again. In the following two sections, the papers will be positioned in the spectrum for collective action introduced here. Each paper falls in a niche in this large spectrum. In Section 2, we present seven papers at different levels of governance; in Section 3, we present three papers that address supply chain management. In Section 4, we conclude by reflecting on major challenges in future research. 


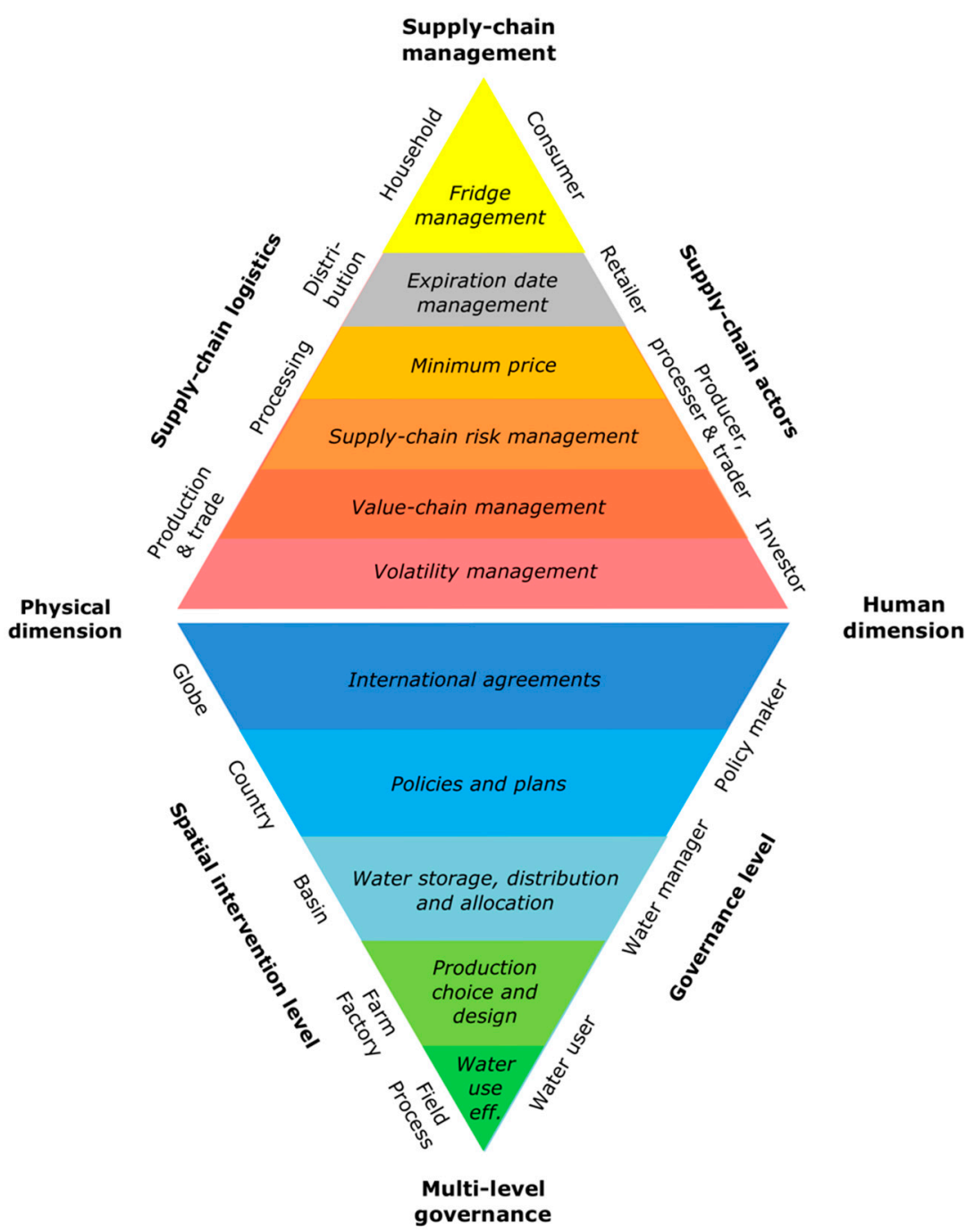

Figure 1. The spectrum of collective action to reduce water footprints of human activities to sustainable levels, along supply chains, and at different scale levels.

\section{Water Footprint Reduction through Multi-Level Governance}

The collection of papers in this volume is illustrative of the fact that water footprint assessments are carried out at different levels. One paper focusses at the farm level with an outlook to the catchment level, considering the water footprint of silk production, which relies on the cultivation of mulberry shrubs that provide leaves to feed the silkworms [10]. Another paper at the farm level analyzes the water footprint of palm oil [11]. The next paper focusses on water footprint assessment at the urban level [12]. Three papers take a river basin perspective on sustainable water use; one of them considers a basin in China [13], another one a basin in Brazil [14], while the third basin-level paper is more theoretical in nature [15]. The last paper presented in this section is a water footprint application at the country level, with an international perspective by including the domestic water implications of international trade [16]. In this bundle of articles, we have no paper that focusses on the global level, but there are plenty of examples outside this volume (e.g., [17,18]).

In a farm-focused study, Hogeboom and Hoekstra [10] estimate water and land footprints and economic productivity as factors in local crop choice, for a case in Malawi where farmers consider to shift from traditional rainfed crops to irrigated sericulture (silk production). For farmers, it is interesting to look at how they can best use the water and land resources that they have access to. The authors explore how information on water and land footprints, and on economic water and land productivity can inform micro-level decision making of crop choice, in the macro-level context of 
sustainable resource use at the catchment level. For a proposed sericulture project in Malawi, they calculate water and land footprints and economic water and land productivities of silk production. They compare the growing of mulberry trees to current crops and address the implications of water consumption at the catchment scale. The study finds that farmers may prefer irrigated mulberry cultivation for silk production over currently grown rain-fed staple crops because its economic water and land productivity is higher than that for the crops currently cultivated. However, because the water footprint will be higher, sericulture will increase the pressure on local water resources. The authors point out that optimizing water and land use at the farm level may result in total water and land footprints at the catchment level that are in conflict with sustainable resource use. In the case studied, however, water consumption in the catchment does not exceed the maximum sustainable footprint (i.e., water consumption remains below the amount that can sustainably be consumed without affecting the environmental flow requirements in the catchment), so that sericulture seems a viable alternative crop for farmers, as long as the production remains small-scale.

In a second farm-based study, Safitri et al. [11] analyze the variation of water use by oil palm plants for different crop ages and different soil types, in a village in Central Kalimantan, Indonesia. They conclude that water use depends on crop age. As root density increases with crop age, root water uptake also increases. Furthermore, they find that the water footprint of oil palm fresh fruits for spodosol soils is considerably smaller than for inceptisol and ultisol soils. The results of this study suggest that there are relevant differences in water footprints, both in space and time, which could be relevant for farmers and other actors aiming at more sustainable agricultural water management.

In their urban-focused paper, Fialkiewicz et al. [12] propose a simplified direct water footprint model to support urban water management. The paper explores how WFA can help to formulate strategies for urban water management with case studies from three different cities in the European Union, namely Wroclaw (Poland), Innsbruck (Austria), and Vicenza (Italy). The study focuses on the internal availability and use of water resources in the urban area to support decision-making in managing local resources. It excludes water used in urban agriculture. It simplifies the accounting phase by schematizing the urban area into different zones based on land cover, including impermeable surfaces, permeable surfaces, and water areas. Green, blue, and grey water footprints are estimated following Hoekstra et al. [19]. The authors compare the results with a more detailed modular approach. The study finds that the simplified water footprint accounting results are within $\pm 3 \%$ to $28 \%$ of more detailed studies. It is shown how the results obtained for the three cities could be the base for drawing up urban water management plans or strategies. The study is a good example of how even without a complex and detailed data-rich assessment, a simplified water footprint assessment can also help decision makers to take effective measures in local water management.

In a basin-focused study, Han et al. [13] assess the green, blue, and grey water footprint of wheat and maize production, in the Haihe River Basin in Northern China. They analyze the temporal trends and spatial variations of the water footprint during the period 1956-2015. It is shown that the water footprint per unit of wheat and maize have decreased, but that increased production has led to a growing pressure on the environment, mainly due to increasing loads of nitrogen into the environment. Given that the grey water footprint is larger than the blue water footprint in recent decades it seems evident that reducing fertilizer use and increasing fertilizer use efficiency could substantially contribute to the reduction of the overall water footprint in the basin. The authors show that high spatial and temporal detail can be helpful to inform basin-level water management decisions aiming to (prioritize locations for taking measures that can) increase water use efficiency and reduce water pollution.

Lathuillière et al. [14] take a basin focus as well and evaluate water use for agricultural intensification in Xingu Basin of Mato Grosso (XBMT), which is part of the Amazon basin in Brazil, using the water footprint sustainability assessment method. They analyze the sustainability of water use based on the resultant green and blue water scarcity in the years 2000 and 2014, and under deforestation and climate change scenarios for 2030 and 2050. The study finds that although the blue water footprint in the basin is currently within the limit of what is still sustainable, under the 
future expansion of irrigation and cattle confinement, blue water scarcity will move from low to moderate, making the production system vulnerable in dry years. Both options for future production changes (either the expansion of agricultural land use or the intensification of productions) have consequences for future water availability, e.g., continued reduction in natural vegetation cover, which is accompanied by reduced water vapor supply to the atmosphere affecting terrestrial ecosystems that rely on precipitation for ecosystem functioning, while dry season water consumed in intensified livestock and irrigation systems will impact aquatic ecosystems downstream. This study provides an important case for estimating blue and green water scarcities in the context of land use change, climate change, and agricultural production scenarios applied for a river basin in Brazil.

Ruddell [15] proposes the use of a theoretical model with a threshold that determines the point beyond which the blue water footprint in a river basin starts to have adverse environmental impacts. The impacts grow exponentially with increasing blue water footprint beyond the threshold. He introduces a volumetric threshold-based water footprint (TWF), defined as the part of the blue water footprint in a basin that exceeds the adverse-impact threshold. The part of the blue water footprint below the threshold is called "free footprint" because it is not associated with adverse environmental impacts. The TWF indicator is compared with the volumetric blue water footprint (BWF) and the water-scarcity weighted BWF indicator that has been used in the life-cycle assessment community. The paper is in line with earlier publications that propose to set a cap on the blue water footprint in a river basin as a policy instrument to prevent adverse environmental impacts from water consumption [20]. An important question remains on how to define the threshold or cap practically.

Karandish and Hoekstra [16] take a national perspective and explore how national food and water security policy can be informed through water footprint assessment, for the case of Iran. They argue that Iran's focus on food self-sufficiency has resulted in investments directed towards increasing water supplies to farmers while neglecting the role of consumption and trade. The authors quantify the green and blue water footprint of crop production in the country, per province, for 26 crops over the period 1980-2010, as well as the water footprint related to crop consumption per province. Furthermore, they quantify provincial virtual water imports and exports in relation to international and inter-provincial crop trade and subsequently estimate the water saving per province associated with this trade. They find that, over the period considered, the water footprint per unit of crop increased rather than decreased for many crops in various regions, with the blue share in the total water footprint increasing nearly everywhere (because of increased irrigation). Combined with the increased production, this led to an increase in the total water footprint of national crop production with a factor 2.2. By 2010, about a quarter of the total water consumption in the semi-arid parts of Iran served the production of crops for export to other regions within the country (mainly cereals) or abroad (mainly fruits and nuts). The authors argue that Iran's food and water policy could be enriched by reducing the water footprints of crop production to certain benchmark levels per crop and climatic region and aligning cropping patterns to spatial differences in water availability and productivities, and by paying due attention to the increasing food consumption per capita in Iran.

\section{Water Footprint Reduction through Supply-Chain Management}

Three papers in this volume approach the water footprint from a supply-chain rather than from a geographic perspective. One paper considers water consumption along the supply chain of wheat bread [21], while another paper considers the water footprint of food waste along the chain [22]. A third paper studies the relation between the demand for biofuels and green water resources use and scarcity [23]. To start with, Mohlotsane et al. [21] quantify and assess green, blue, and grey water footprints along the wheat-bread value chain in South Africa. Water footprints are analyzed in the context of economic water productivity. The authors find that the wheat-bread value chain is becoming more blue-water intensive, which is a critical factor in water resources management as South Africa is experiencing higher frequency and degrees of blue water scarcity recently. As the local context defines 
the sustainability of water footprint in the value chain, the study is a fine example highlighting the need for catchment- or region-specific water footprint benchmarks.

Roux et al. [22] assess the blue water footprint of vegetable crop wastage along the supply chain in a case for South Africa. They focus on food waste in the value chain rather than the food finally consumed at the end of the value chain. This study aimed to quantify indirect blue water losses through the wastage of vegetable crops produced in a major production region on the Steenkoppies Aquifer located west of Tarlton in Gauteng, South Africa. The total water withdrawal from the aquifer is 25 million $\mathrm{m}^{3}$ per year while the sustainability threshold of this aquifer is only 17 million $\mathrm{m}^{3}$ per year. In this context, the estimated blue water footprint of 4 million $\mathrm{m}^{3}$ per year resulting from the wastage of carrots, cabbage, beetroot, broccoli, and lettuce, is significant in managing the water scarcity in the region. The paper concludes that reducing such wastage not only contributes to the sustainability of water use in the region but also reduces other negative environmental impacts resulting from the use of fertilizers, pesticides, and energy.

$\mathrm{Xu}$ and $\mathrm{Wu}$ [23] make a first estimation of county-based green water availability and its implications for agriculture and bioenergy production in the United States. Water resources assessments still often focus on blue water consumption versus blue water availability, while comparing green water consumption versus green water availability is as relevant [24]. $\mathrm{Xu}$ and $\mathrm{Wu}$ [23] define a green water availability index as the fraction of green water resources that, after the green water demand of specified sectors (e.g., agriculture) has been met, is available to the remaining green water users (e.g., timber, pasture, ecosystem services). In the paper, they quantify, for each county in the US, the fraction of green water resources needed if the water demands of three major crops (corn, soybeans, and wheat) in the county are met by green water, and the fraction of green water resources in the county that is available to remaining green water users (other crops, grassland, forest, and ecosystem services). They also estimate how much green water resources are available for non-bioenergy purposes after fulfillment of the crop water demand of all corn and soybeans grown specifically for biofuel feedstock.

\section{Conclusions}

Water footprint studies are available at all levels, as indicated in Figure 1, from studies that consider how to reduce the water footprint in a crop field or industrial production unit to global-level studies. The current volume presents several illustrative examples at different levels, notably the farm, urban, basin, and country level. Still, a weak point in water footprint literature is how these different levels are connected. One relevant question is how local-scale actions (e.g., crop choice or water use efficiency increase) together can contribute to the solution of problems at higher levels (e.g., water scarcity at basin level or international burden shifting through trade) and how global actions (e.g., international agreement on sustainable trade) can contribute to the solution of local water problems. Another relevant question is how actions at different levels can create synergies to make the water footprint of our production and consumption patterns more sustainable, with due attention to local carrying capacities.

The water footprint concept is integrative by nature by its applicability at different levels (local to global) and along supply chains (from investment and production to processing, sales, and consumption). The full potential of water footprint analysis along supply chains needs to be realized still though. As the papers in the current collection show, methods to localize and quantify water footprints in the various steps of the supply chain of a product are improving; for many products, particularly agricultural products, we understand how water footprints vary with climate, soil and production practices, and how water footprints can be reduced by changing policies and applying better technologies and practices. Obtaining good local data, however, remains difficult. Perhaps even more challenging is to improve our understanding of the interactions between actors along the supply chain, for instance: how can consumers motivate retailers and producers to reduce the water footprint of products in the hotspots along the product supply chain; how can companies influence suppliers through sustainable procurement strategies that include water criteria; how will water 
pricing affect final commodity prices and thus potentially influence consumer decisions; and how could the inclusion of water criteria in environmental product labels bring about sustainable water use along the supply chain.

Despite the considerable progress in the water footprint assessment research field, the research field is still largely focusing on challenges in modeling and quantification, with major challenges remaining in the translation of data and insights to coherent mechanisms of governance and ways of intervention, along supply chains and at different levels.

Author Contributions: The authors contributed equally to the writing of this editorial.

Conflicts of Interest: The authors declare no conflict of interest.

\section{References}

1. Feng, K.; Hubacek, K.; Minx, J.; Siu, Y.L.; Chapagain, A.; Yu, Y.; Guan, D.; Barrett, J. Spatially explicit analysis of water footprints in the UK. Water 2011, 3, 47-63. [CrossRef]

2. Zhang, G.P.; Hoekstra, A.Y.; Mathews, R.E. Water Footprint Assessment (WFA) for better water governance and sustainable development. Water Resour. Ind. 2013, 1-2, 1-6. [CrossRef]

3. Hoekstra, A.Y.; Chapagain, A.K.; Zhang, G.P. Water footprints and sustainable water allocation. Sustainability 2016, 8, 20. [CrossRef]

4. Hoekstra, A.Y.; Chapagain, A.K.; Van Oel, P.R. Advancing water footprint assessment research: Challenges in monitoring progress towards Sustainable Development Goal 6. Water 2017, 9, 438. [CrossRef]

5. Hoekstra, A.Y. Water footprint assessment: Evolvement of a new research field. Water Resour. Manag. 2017, 31, 3061-3081. [CrossRef]

6. Savenije, H.H.G.; Hoekstra, A.Y.; Van der Zaag, P. Evolving water science in the Anthropocene. Hydrol. Earth Sys. Sci. 2014, 18, 319-332. [CrossRef]

7. Di Baldassarre, G.; Wanders, N.; AghaKouchak, A.; Kuil, L.; Rangecroft, S.; Veldkamp, T.I.E.; Garcia, M.; van Oel, P.R.; Breinl, K.; Van Loon, A.F. Water shortages worsened by reservoir effects. Nat. Sustain. 2018, 1, 617-622. [CrossRef]

8. Grafton, R.Q.; Williams, J.; Perry, C.J.; Molle, F.; Ringler, C.; Steduto, P.; Udall, B.; Wheeler, S.A.; Wang, Y.; Garrick, D.; et al. The paradox of irrigation efficiency. Science 2018, 361, 748. [CrossRef]

9. Distefano, T.; Kelly, S. Are we in deep water? Water scarcity and its limits to economic growth. Ecol. Econ. 2017, 142, 130-147. [CrossRef]

10. Hogeboom, R.J.; Hoekstra, A.Y. Water and land footprints and economic productivity as factors in local crop choice: The case of silk in Malawi. Water 2017, 9, 802. [CrossRef]

11. Safitri, L.; Hermantoro, H.; Purboseno, S.; Kautsar, V.; Saptomo, S.K.; Kurniawan, A. Water footprint and crop water usage of oil palm (Eleasis guineensis) in Central Kalimantan: Environmental sustainability indicators for different crop age and soil conditions. Water 2019, 11, 35. [CrossRef]

12. Fialkiewicz, W.; Burszta-Adamiak, E.; Kolonko-Wiercik, A.; Manzardo, A.; Loss, A.; Mikovits, C.; Scipioni, A. Simplified direct water footprint model to support urban water management. Water 2018, 10, 630. [CrossRef]

13. Han, Y.; Jia, D.; Zhuo, L.; Sauvage, S.; Sánchez-Pérez, J.-M.; Huang, H.; Wang, C. Assessing the water footprint of wheat and maize in Haihe River Basin, Northern China (1956-2015). Water 2018, 10, 867. [CrossRef]

14. Lathuillière, M.J.; Coe, M.T.; Castanho, A.; Graesser, J.; Johnson, M.S. Evaluating water use for agricultural intensification in Southern Amazonia using the Water Footprint Sustainability Assessment. Water 2018, 10, 349. [CrossRef]

15. Ruddell, B.L. Threshold based footprints (for water). Water 2018, 10, 1029. [CrossRef]

16. Karandish, F.; Hoekstra, A.Y. Informing national food and water security policy through water footprint assessment: The case of Iran. Water 2017, 9, 831. [CrossRef]

17. Wang, R.; Zimmerman, J. Hybrid analysis of blue water consumption and water scarcity implications at the global, national, and basin levels in an increasingly globalized world. Environ. Sci. Technol. 2016, 50, 5143-5153. [CrossRef]

18. Yang, C.; Cui, X. Global changes and drivers of the water footprint of food consumption: A historical analysis. Water 2014, 6, 1435-1452. [CrossRef] 
19. Hoekstra, A.Y.; Chapagain, A.K.; Aldaya, M.M.; Mekonnen, M.M. The Water Footprint Assessment Manual: Setting the Global Standard; Earthscan: London, UK, 2011.

20. Hoekstra, A.Y. Sustainable, efficient and equitable water use: The three pillars under wise freshwater allocation. WIREs Water 2014, 1, 31-40. [CrossRef]

21. Mohlotsane, P.M.; Owusu-Sekyere, E.; Jordaan, H.; Barnard, J.H.; Van Rensburg, L.D. Water footprint accounting along the wheat-bread value chain: Implications for sustainable and productive water use benchmarks. Water 2018, 10, 1167. [CrossRef]

22. Roux, B.L.; Van der Laan, M.; Vahrmeijer, T.; Annandale, J.G.; Bristow, K.L. Water footprints of vegetable crop wastage along the supply chain in Gauteng, South Africa. Water 2018, 10, 539. [CrossRef]

23. Xu, H.; Wu, M. A first estimation of county-based green water availability and its implications for agriculture and bioenergy production in the United States. Water 2018, 10, 148. [CrossRef]

24. Schyns, J.F.; Hoekstra, A.Y.; Booij, M.J.; Hogeboom, H.J.; Mekonnen, M.M. Limits to the world's green water resources for food, feed, fibre, timber and bio-energy. Proc. Natl. Acad. Sci. USA 2019, 116, 4893-4898. [CrossRef]

(C) 2019 by the authors. Licensee MDPI, Basel, Switzerland. This article is an open access article distributed under the terms and conditions of the Creative Commons Attribution (CC BY) license (http://creativecommons.org/licenses/by/4.0/). 